\title{
RESPONS MAHASISWA TERHADAP PERKULIAHAN PADA PROGRAM STUDI PENDIDIKAN BAHASA DAN SASTRA INDONESIA FKIP UNIVERSITAS SURYAKANCANA TAHUN 2015/2016
}

\author{
Siti Maryam ${ }^{1}$, Sukaesih $^{2}$, Daud Pamungkas ${ }^{3} \&$ Cinde Adia Diningsih ${ }^{4}$ \\ FKIP Universitas Suryakancana \\ Email : yams1964@yahoo.com
}

\begin{abstract}
ABSTRAK
Artikel ini mendeskripsikan respons mahasiswa terhadap perkuliahan pada Program Studi Pendidikan Bahasa dan Sastra Indonesia FKIP Universitas Suryakancana (Unsur), meliputi delapan aspek, yakni tanggapan mahasiswa terhadap kualitas materi perkuliahan, penguasaan dosen terhadap materi perkuliahan yang disajikannya, strategi perkuliahan, efektivitas kerja kelompok mahasiswa, pelayanan dosen terhadap mahasiswa, pemanfaatan alokasi waktu, pemanfaatan media pembelajaran, dan pengorganisasian kelas. Penelitian menggunakan metode deskriptif dengan teknik penelitian menggunakan Bull Eyes. Hasil penelitian menunjukkan bahwa respons mahasiswa terhadap kedelapan aspek yang diteliti rata-rata berkategori baik. Tindak lanjut dari hasil penelitian ini akan digunakan untuk meningkatkan kualitas proses perkuliahan dan meningkatkan kompetensi dosen serta lulusan Program Studi Pendidikan Bahasa dan Sastra Indonesia FKIP Unsur.
\end{abstract}

Kata kunci: perkuliahan, mahasiswa, respons, bull eyes.

\section{ABSTRACT}

This article describes the response of the students to lecture on Language and Literature Indonesian Departement FKIP Suryakancana University, covering eight aspects, namely the response of students to the quality of lecture material, mastery lecturers to lecture material it presents, the strategy of the course, the effectiveness of student groups, service faculty to students, use of time allocation, utilization of instructional media, and organizing classes. The research uses descriptive method by using a research technique Bull Eyes. The results showed that the response of students to the eighth aspects studied well the average category. Not up to the results of this study will be used to improve the quality of the lecture and improve the competence of lecturers and graduate Language and Literature Indonesian Departement FKIP Suryakancana University .

Keywords: college, student, response, bull eyes

\section{PENDAHULUAN}

Kajian ini dilatarbelakangi tantangan bahwa pembelajar di masa depan antara lain perlu memiliki kemampuan berkomunikasi, kemampuan berpikir jernih dan kritis, kemampuan menjadi warga negara yang bertanggung jawab. Relevan dengan tantangan di atas, mahasiswa perlu diberi kesempatan untuk mengungkapkan pendapatnya, gagasan-gagasannya, dan sikapnya terhadap perkuliahan yang diikutinya. 
Sebelumnya, Nugraheni (2012) menemukan kebutuhan mahasiswa terhadap matakuliah yang diampunya, yakni mata kuliah bahasa Indonesia di PTAIN. Mahasiswa mengharapkan mata kuliah tersebut diisi dengan keterampilan menulis ilmiah. Hal itu sesuai dengan tuntutan publikasi ilmiah bagi lulusan S1.

Aktivitas mahasiswa dalam perkuliahan tentunya harus sejalan dengan perubahan paradigma pendidikan yang menganggap bahwa pembelajaran harus berpusat kepada peserta didik, di perguruan tinggi mahasiswa merupakan peserta didiknya. Hal ini sejalan dengn konsep pembelajaran aktif yang termaktub dalam Permen Diknas Nomor 41, Tahun 2007.

Mahasiswa sebagai subjek penelitian didorong untuk mengungkapkan pandangan, pendapat, dan gagasannya sepanjang penelitian berlangsung. Mahasiswa sebagai sumber daya manusia masa depan, pemberdayaannya dalam pendidikan perlu ditangani secara profesional. Upaya peningkatan kualitas perkuliahan dilakukan Program Studi Pendidikan Bahasa dan Sastra Indonesia (selanjutnya disebut prodi) selama ini terus berlangsung. Beberapa upaya itu, di antaranya perekrutan dosen, pengadaan sarana prasarana, penerbitan jurnal, peningkatan jumlah mahasiswa dan dosen penerima beasiswa, pembinaan dosen melalui pertemuan rutin bulanan, pengiriman dosen untuk workshop dan lain-lain. Berhasil tidaknya upaya tersebut mesti dilakukan evaluasi baik secara internal maupun eksternal.

Mengapa proses perkuliahan perlu diteliti? Brown (2007: 2) menghubungkan antara proses pembelajaran dengan keberhasilan pembelajaran. Selanjutnya, Brown (2007: 3) mengungkapkan, "Kita diatur konsekuensi-konsekuensi atas perilaku kita, dan karena itulah Skinner bahwa kita, dalam mengkaji perilaku manusia, harus mempelajari efek konsekuensi-konsekuensi tersebut". Selain itu, penelitian ini pun merupakan tindak lanjut dari penelitian sebelumnya yang mengatakan bahwa proses perkuliahan masih perlu ditingkatkan, di antaranya berkenaan dengan masih adanya penggunaan model dan metode yang konvensional, perkuliahan yang hanya menekankan pada ranah kognitif, masih minimnya mata kuliah yang berpraktikum, dan dirasa masih kurang memperhatikan ranah afektif.

Berdasarkan permasalahan di ata serta mengacu pada pencapaian visi misi program studi, penelitian ini dilakukan. Selain itu, hasil penelitian akan dijadikan bahan masukan bagi penyusunan kurikulum berdasarkan Kerangka Kualifikasi Nasional Indonesia (KKNI) yang akan segera diberlakukan di FKIP Universitas Suryakancana Tahun akademik 2016-/2017.

Penelitian ini berfokus pada proses perkuliahan sehingga tanggapan mahasiswa pun diarahkan pada aspekaspek proses perkuliahan, yakni: kualitas materi perkuliahan; penguasaan dosen terhadap materi perkuliahan; penggunaan strategi perkuliahan; efektivitas kerja kelompok (kolaborasi); pelayanan dosen terhadap mahasiswa; pemanfaatan alokasi waktu; pemanfaatan media pembelajaran; pengorganisasian kelas. Adapun tujuan penelitian untuk mengetahui respons mahasiswa terhadap pelaksanaan perkuliahan di Program Studi Pendidikan Bahasa dan Sastra Indonesia FKIP Universitas Suryakancana.

Hasil penelitian diharapkan dapat bermanfaat baik secara teoretis maupun praktis. Secara teoretis penelitian ini dapat mengembangkan teori respons dan teori pembelajaran bahasa. Secara praktis, dapat dijadikan bahan umpan balik, motivasi belajar, perbaikan 
kurikulum, pengembangan ilmu, diagnosis dan atau remedial. Selain itu, dapat dijadikan sarana untuk mengukur kekuatan dan kelemahan dosen sebagai agent of change di Lembaga Pendidikan Tenaga Kependidikan (LPTK), khususnya di Program Studi PBSI FKIP Universitas Suryakancana Cianjur.

Kerangka konseptual penelitian dibangun dari konsep bahwa respons mahasiswa merupakan penilaian hasil belajar yang terpadu dengan proses perkuliahan. Mahasiswa sebagai subjek perkuliahan memiliki hak untuk merespons terhadap beragam aspek perkuliahan yang dipajankan kepadanya.

Landasan pokok dalam penelitian mencakup a) strategi perkuliahan, b) materi perkuliahan, c) penguasaan materi, d) alokasi waktu, e) media pembelajaran, f) organisasi kelas, g) respon terhadap mahasiswa, dan h) efektivitas kelompok belajar. Secara berturut-turut kedelapan aspek tersebut disajikan berikut ini.

Strategi atau teknik merupakan prosedur-prosedur yang digunakan untuk mencapai yang telah ditetapkan. Secara umum kata "strategi" mengandung makna rencana yang cermat mengenai kegiatan untuk mencapai sasaran khusus (Moeliono,1988: 859). Istilah strategi dan teknik sering dipakai secara bergantian kedua-duanya bersinonim. Untuk memahami strategi secara dalam, biasanya dikaitkan dengan istilah pendekatan, metode dan teknik (Tarigan,1991:3). Pendekatan adalah seperangkat asumsi korelatif yang menangani hakikat pengajaran dan pembelajaran bahasa.

Sagala (2007:221) Konsep dasar strategi belajar mengajar meliputi halhal (1) menetapkan spesifikasi dan kualifikasi perubahan perilaku belajar, (2) menentukan pilihan berkenaan dengan pendekatan terhadap masalah belajar mengajar, memilih prosedur, metode dan teknik belajar mengajar, dan (3) norma dan kriteria keberhasilan kegiatan belajar mengajar.

Semua materi perkuliahan pada dasarnya merupakan learning resources yang memfasilitasi kegiatan perkuliahan agar mahasiswa memperoleh kompetensi, baik, dalam dimensi pengetahuan, sikap, maupun keterampilan. Materi perkuliahan untuk mengembangkan kompetensi tersebut tentunya harus memenuhi kriteria, Hidayat (1991: 67) menyebutkan kriteria memilih materi pembelajaran meliputi: (1) isi pembelajaran hendaknya cukup valid, artinya kebenaran materi tidak disangsikan dan dapat dipahami untuk mencapai tujuan; (2) bahan yang diberikan harus cukup berarti atau bermanfaat, hal ini berhubungan dengan keluasan dan kedalaman bahan; (3) bahan hendaknya menarik; dan (4) bahan hendaknya berada dalam batas-batas kemampuan pembelajar.

Kemampuan dosen dalam menguasai materi dapat dilihat mulai dari tahap perencanaan, yakni kemampuannya dalam menyusun Rencana Perkuliahan Semester (RPS). Pada awal perkuliahan, pertemuan pertama, dosen wajib menyampaikan RPS kepada mahasiswa di kelas. Dari informasi tersebut, mahasiswa diharapkan sudah mengetahui dan menyadari kompetansi yang akan dicapai melalui perkuliahan. Perkuliahan yang baik tentunya akan banyak mengundang mahasiswa untuk bertanya dan atau menanggapi pertanyaan. Oleh karena itu, dosen dituntut untuk mampu melaksanakan perkuliahan sesuai dengan RPS yang disusunnya. Sebagaimana diketahui, RPS berperan sebagai pemandu perkuliahan. Dalam pelaksanaannya, perkuliahan tersebut dilengkapi dengan media pembelajaran dan sumber belajar yang relevan dengan tujuan pembelajaran yang akan dicapai. 
Penyampaian materi dalam perkuliahan hendaknya direncanakan dengan baik, sehingga dapat disajikan dengan urutan yang cocok. Rusman $(2011 ; 87)$ mengatakan pemberian penjelasan merupakan aspek yang sangat penting dari kegiatan dosen dalam interaksi dengan mahasiswa di dalam kelas. Tujuannya sebagai berikut.

Membimbing mahasiswa untuk dapat memahami konsep, hukum, dalil, fakta, dan prinsip secara objektif dan bernalar.

a) Melibatkan mahasiswa untuk berpikir dengan memecahkan masalah-masalah atau pertanyaan.

b) Mendapatkan balikan dari mahasiswa mengenai tingkat pemahamannya dengan untuk mengatasi kesalahpahaman mahasiswa.

c) Membimbing mahasiswa untuk menghayati dan mendapat proses penalaran dan menggunakan bukti-bukti dalam memecahkan masalah (Rusman, 2011:88).

Keterampilan mengelola waktu perkuliahan harus dimiliki dosen. Untuk setiap pokok bahasan dalam satu semester perlu dicantumkan jumlah waktu yang dialokasikan, sehingga sejak awal sudah dapat diketahui apakah program semester yang dibuat itu dapat diselesaikan pada waktunya. Jika melebihi waktu yang tersedia, maka perlu diadakan penyesuaian-penyesuaian dalam materi maupun alokasi waktu.

Isi dan alokasi waktu setiap mata kuliah bergantung pada luas dan sempitnya pokok bahasan yang dicakupnya. Pokok bahasan yang membutuhkan waktu 2 SKS, mungkin selesai diajarkan dalam satu pertemuan saja (100 menit). Pokok bahasan yang membutuhkan waktu 4 SKS, perlu disampaikan dalam dua pertemuan penyajian, demikian seterusnya. Silabus dan Rencana Perkuliahan Semester (RPS) dijadikan pegangan dan acuan untuk mengajar di kelas yang memuat jumlah dan waktu pertemuan.

Media merupakan salah satu aspek yang perlu dikuasai dosen di samping pengelolaan kelas. Media adalah segala sesuatu yang dapat digunakan unyuk menyalurkan pesan (materi pembelajaran), merangsang pikiran, segala sesuatu yang dapat digunakan untuk menyalurkan pesan (materi pembelajaran), merangsang pikiran, perasaan, perhatian dan kemampuan mahasiswa, sehingga dapat mendorong proses pembelajaran (Rusman, 2011:77). Tujuan pemanfaatan media agar perkuliahan berjalan efektif dan efesien, karena media yang tepat akan mampu menarik dan memfokuskan perhatian mahasiswa.

Kemampuan menggunakan media tidak hanya yang sudah tersedia seperti media cetak, media audio,dan media audio visual. Tetapi kemampuan dosen di sini lebih ditekankan pada penggunaan objek nyata yang ada di sekitar. Dalam kenyataan di lapangan dosen dapat memanfaatkan media yang sudah ada (by utilization) seperti globe, peta, gambar dsb., atau dosen dapat mendesain media untuk kepentingan pembelajaran (by design) seperti membuat media foto, film berbasis komputer. Hal ini penting karena tipe mahasiswa sangat heterogen ada yang auditf, visual, dan kinestetis.

Organisasi pembelajaran mengacu pada kelompok fungsional seperti yang dijelaskan Fattah (2001:71), yakni kumpulan orang dengan sistem kerja sama untuk mencapai tujuan bersama. Karakteristik sistem kerja sama dapat dilihat antara lain (1) ada komunikasi antara orang yang bekerja sama; (2) 
individu dalam organisasi tersebut mempunyai kemampuan untuk bekerja sama; dan (3) kerja sama itu ditujukan untuk mencapai tujuan. Jadi, pengorganisasian sebagai proses membagi kerja ke dalam tugas-tugas yang lebih kecil, membebankan tugas-tugas itu kepada orang yang sesauai dengan kemampuannya, dan mengalokasikan sumber daya, serta mengkoordinasikannya dalam rangka efektivitas pencapain tujuan organisasi (dalam hal ini tujuan perkuliahan).

Efektivitas kelompok sangat bergantung pada sudut pandang, apakah kelompok itu efektif bagi individu dalam kelompok, atau kelompok itu efektif untuk kepentingan organisasi. Dilihat dari kepentingan organisasi efektivitas organisasi sangat bergantung pada seberapa jauh pimpinan mampu mengelola bawahannya. Dalam perkuliahan, dapat dipandang cara dosen mengelola mahasiswa.

Ukuran efektivitas kelompok sangat bervariasi, antara lain: (1) produktivitas (hasil), (2) derajat kepuasan, (3) kreativitas, (4) intensitas emosi (Fatah, 2001 : 84). Masalah pengukuran efektivitas kelompok disulitkan juga oleh kenyataan bahwa efektivitas itu sendiri dari kelompok apa saja merupakan variabel yang multidimensional. Tiap anggota kelompok mempunyai kepuasan keinginan yang berbeda-beda satu sama lain, walaupun berada dalam satu kelompok. Satu kelompok dapat efektif terhadap anggota lainnya. Efektivitas kelompok kerja sering diukur dari sudut produktivitasnya.

Makna respons menurut Walyo (1990: 149) adalah 1) Jawaban, tanggapan, balasan 2) sembarang aksi yang nampak atau tersembunyi. Berkenaan dengan respons Maryam (2006) menjelaskan bahwa ketika seseorang melakukan suatu respons terhadap hal yang dilihat, dibaca atau didengarnya, ia akan mengkonstruksi secara unik sesuai dengan penafsirannya terhadap situasi, peristiwa, atau persoalan tersebut. Pada aktivitas pembelajaran, Wahyudi (2016) menjelaskan bahwa proses pemberian stimulus yang diberikan oleh pengajar kepada pembelajar agar terjadi interaksi dapat digambarkan seperti dalam hukum fisika dimana sutau benda diberikan gaya maka akan terjadi sebuah reaksi terhadap benda tersebut.

Penelitian respons yang dilakukan Thorndike terhadap kucing menghasilkan hukum-hukum belajar, di antaranya:

1. Law of Effect; artinya bahwa jika sebuah respons menghasilkan efek yang memuaskan, maka hubungan StimulusRespons akan semakin kuat. Sebaliknya, semakin tidak memuaskan efek yang dicapai respons, maka semakin lemah pula hubungan yang terjadi antara Stimulus-Respons.

2. Law of Readiness; artinya bahwa kesiapan mengacu pada asumsi bahwa kepuasan organisme itu berasal dari pendayagunaan satuan pengantar (conduction unit), dimana unit-unit ini menimbulkan kecenderungan yang mendorong organisme untuk berbuat atau tidak berbuat sesuatu.

3. Law of Exercise; artinya bahwa hubungan antara Stimulus dengan Respons akan semakin bertambah erat, jika sering dilatih dan akan semakin berkurang apabila jarang atau tidak dilatih

Aplikasi Teori Thorndike dalam dunia pendidikan dan pengajaran, menurut Thorndike praktik pendidikan harus dipelajari secara ilmiah dan praktik pendidikan harus dihubungkan dengan proses belajar. Mengajar yang baik adalah, tahu tujuan pendidikan, tahu apa yang hendak diajarkan artinya tahu materi apa yang harus diberikan, respons yang akan diharapkan dan tahu kapan 
"hadiah" selayaknya diberikan kepada peserta didik. Beberapa aturan yang dibuat Thorndike berhubungan dengan pengajaran:

1. Perhatikan situasi peserta didik.

2. Perhatikan respons yang diharapkan dari situasi tersebut.

3. Ciptakan hubungan respons tersebut dengan sengaja, jangan mengharapkan hubungan terjadi dengan sendirinya.

4. Situasi-situasi yang sama jangan diindahkan sekiranya memutuskan hubungan tersebut.

5. Buat hubungan sedemikian rupa sehingga menghasilkan perbuatan nyata dari peserta didik.

6. Bila hendak menciptakan hubungan tertentu jangan membuat hubunganhubungan lain yang sejenis.

\section{METODE PENELITIAN}

Sesuai dengan tujuan, metode yang digunakan dalam penelitian adalah metode deskriptif. Pengumpulan data dilakukan dengan menggunakan Bull Eyes. Teknik pengolahan data dilakukan dengan cara mempersentasekan hasil respons mahasiswa. Penelitian dimulai dari Desember 2015 sampai dengan Mei 2016.

Pada penelitian, data yang berhasil dikumpulkan selain data kuantitatif, juga berhasil dihimpun data kualitatif yang menggunakan skala Likert: Sangat Puas (SP), Puas (P), Cukup Puas (CP), dan Kurang Puas (KP). Adapun variasi kualitas puas, disesuaikan dengan aspek yang diukur sehingga penggunaan kata sifat tersebut bervariatf seperti menarik untuk strategi, efektif untuk kerja kelompok, dan lainlain. Namun demikian, pada tahap rekapitulasi perhitungan disejajarkan dengan skala tersebut.

Subjek dalam penelitian adalah mahasiswa Program Studi Pendidikan
Bahasa dan Sastra Indonesia Semester I, III, dan V tahun akademik 2015/2016 yang mengikuti perkuliahan di semester ganjil sedangkan mahasiswa semester VII tidak diikutsertakan karena mereka sedang melaksanaka Program Latihan Profesi dan tidak ada perkuliahan di kampus.

Respons mahasiswa terhadap aspek (1) materi perkuliahan, (2) penguasaan dosen terhadap materi perkuliahan, (3) penggunaan strategi perkuliahan, (4) efektivitas kerja kelompok atau kolaborasi, (5) pelayanan dosen terhadap mahasiswa, (6) pemanfaatan alokasi waktu, (7) pemanfaatan media pembelajaran, dan (8) pengorganisasian kelas. Instrumen yang digunakan dalam penelitian ini berupa lembar Bull's Eye berikut.

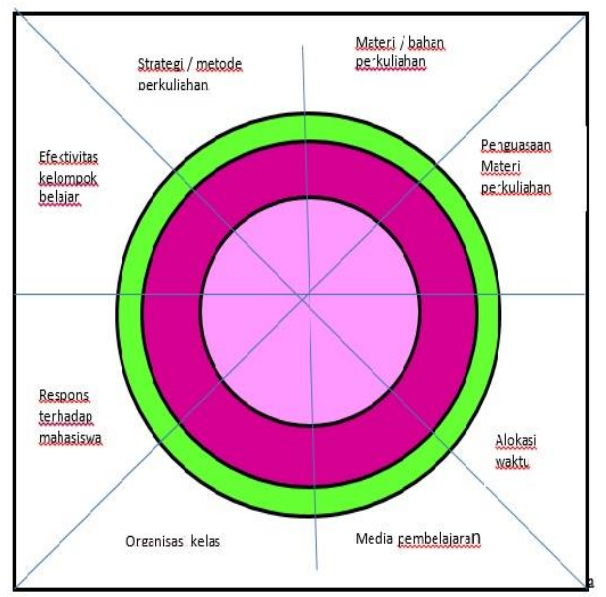

Lembar ini digunakan untuk satu mata kuliah satu lembar. Mahasiswa diminta untuk membubuhkan titik pada bagian-bagian yang terdapat dalam lingkaran tersebut. Jika mereka merasa sangat puas dengan perkuliahan $\mathrm{X}$, maka mahasiswa itu harus membubuhkan titik pada warna merah muda, puas pada merah marun, kurang puas pada hijau, dan tidak puas pada warna putih. Jumlah titik yang dibubuhkan mahasiswa relevan dengan jumlah aspek yang tercantum. 


\begin{tabular}{|c|c|}
\hline $\begin{array}{l}\text { banyak } \\
\text { membantu } \\
\text { mahasiswa } \\
\text { dalam } \\
\text { menambah } \\
\text { banyak } \\
\text { referensi. } \\
\text { Sumber materi } \\
\text { mudah untuk } \\
\text { diakses. } \\
\text { Materi dapat } \\
\text { dpahami } \\
\text { pembelajaran } \\
\text { lebih } \\
\text { mendalam. } \\
\text { Materi } \\
\text { bermanfaat } \\
\text { untuk } \\
\text { memperhalus } \\
\text { budi pekerti. } \\
\text { Dalam setiap } \\
\text { pertemuan } \\
\text { materi } \\
\text { berkembang, } \\
\text { ditambah } \\
\text { dengan } \\
\text { contoh- } \\
\text { fakta empiris } \\
\text { maupun }\end{array}$ & $\begin{array}{ll} & \text { terkadang } \\
\text { sulit } \\
\text { berkembang } \\
\text { e. } & \text { Kurang } \\
\text { jelas, masih } \\
\text { banyak } \\
\text { mendongeng } \\
\text {. }\end{array}$ \\
\hline
\end{tabular}

\begin{tabular}{l}
\hline teoretis. \\
\hline Respons positif maupun negatif \\
merupakan masukan berharga bagi \\
Prodi. Berdasarkan data tersebut Prodi \\
mendapatkan informasi yang terkait \\
dengan mutu mater perkuliahan. Maha- \\
siswa memandang penting keberagam \\
sumber rujukan yang digunakan dalam \\
perkuliahan serta mempertimbangkan \\
manfaat materi perkuliahan. Adapun \\
respons negatif bagi prodi merupakan \\
bahan masukan yang sangat berharga \\
terutama bagi pengembangan kualitas \\
bahan ajar.
\end{tabular}

Selanjutnya, berkenaan dengan penguasaan dosen terhadap materi perkuliahan diperoleh data sebanyak 25\% menyatakan sangat menguasai (SM), 46\% mahasiswa menyatakan menguasai (M), $21 \%$ menyatakan cukup menguasai (CM), dan 8\% menyatakan kurang menguasai (KM) seperti tampak pada diagram di bawah ini.

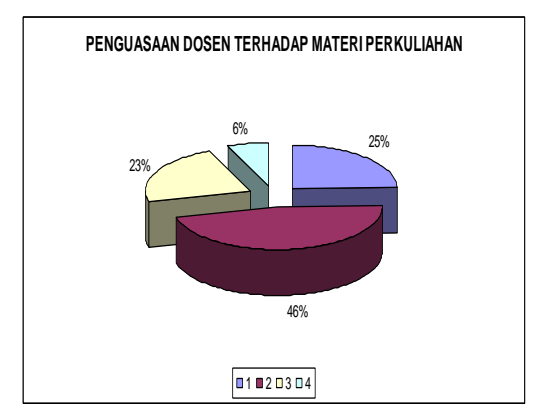

\section{Diagram 2: Penguasaan Dosen terhadap Materi Perkuliahan}

Selain data kuantitatif tersebut, terdapat data kualitatif mahasiswa menilai kualitas penguasaan dosen dari dua sisi, yakni positif dan negatif. Sisi negatif dapat dijadikan bahan pembinaan dan pengembangan kualitas kompetensi profesional dosen.

Tabel 2 Penguasaan Dosen terhadap Materi Perkuliahan

\begin{tabular}{|c|c|}
\hline $\begin{array}{c}\text { Respons Positif } \\
\text { (tidak diedit) }\end{array}$ & $\begin{array}{c}\text { Respons } \\
\text { Negataif (tidak }\end{array}$ \\
\hline
\end{tabular}




\begin{tabular}{|c|c|}
\hline & diedit) \\
\hline 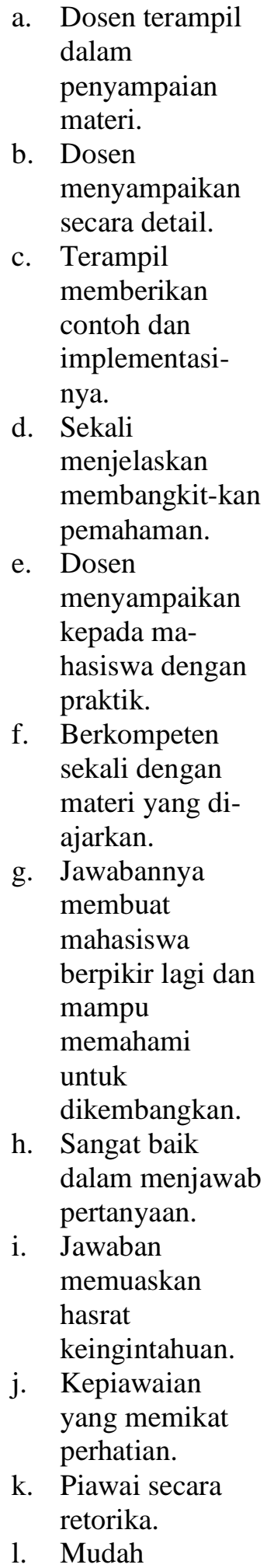 & $\begin{array}{ll}\text { a. } & \text { Hanya } \\
& \text { sebagian } \\
& \text { materi yang } \\
& \text { diperjelas. } \\
\text { b. } & \text { Materi masih } \\
& \text { samar } \\
& \text { dipahami. } \\
\text { c. } & \text { Bertele-tele } \\
\text { dan kurang } & \text { mudah } \\
\text { dipahami. } \\
\text { d. }\end{array}$ \\
\hline
\end{tabular}

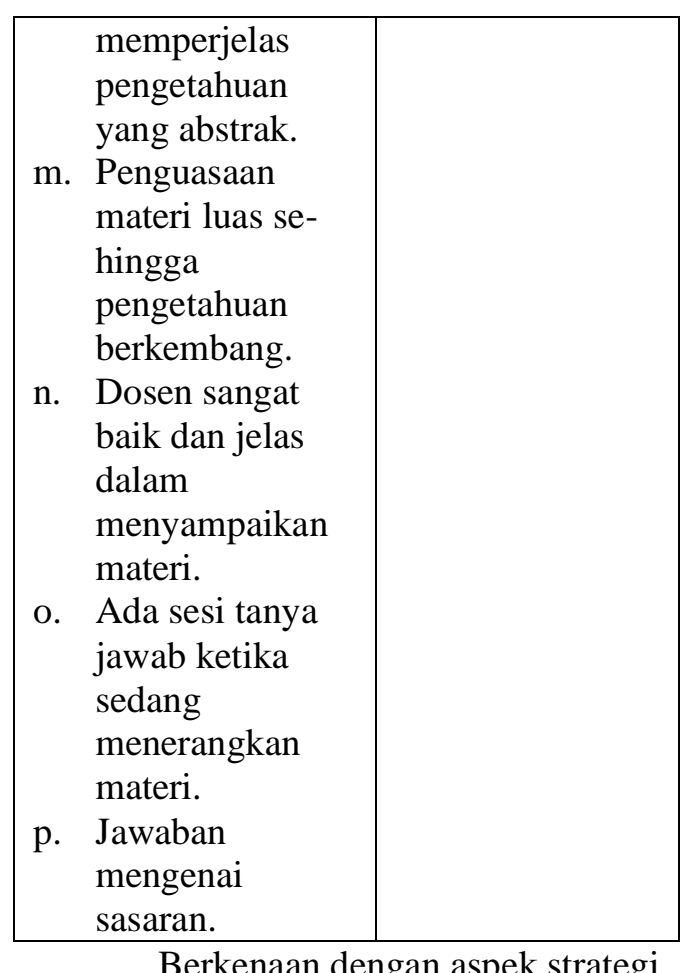

Berkenaan dengan aspek strategi perkuliahan sebanyak $21 \%$ mahasiswa menyatakan bahwa penggunaan strategi perkuliahan yang disajikan dalam perkuliahan di Prodi Pendidikan Bahasa dan Sastra Indonesia sangat menarik (SM), $48 \%$, yang menyatakan menarik (M), $24 \%$ menyatakan cukup menarik (CM), dan 7\% menyatakan kurang menarik (KM) seperti tampak pada diagram berikut.

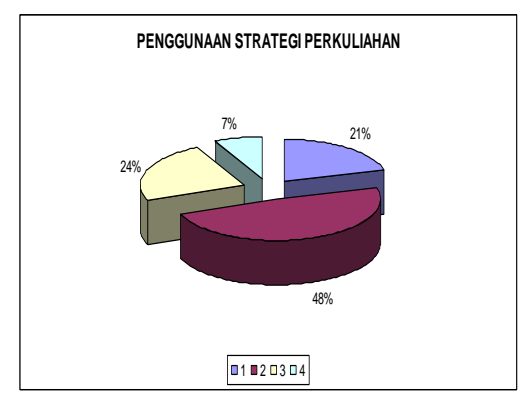

\section{Diagram 3: Penggunaan Strategi Perkuliahan}

Selanjutnya disajikan data kualitatif yang berkenaan dengan respons positif dan negatif penggunaan strategi dalam perkuliahan di Prodi PBSI. Maha- 
siswa memandang penting terhadap penggunaan strategi perkuliahan yang bervariatif sehingga mahasiswa jika ada dosen yang hanya mengunakan sebuah strategi, mahasiswa meresponsnya negatif. Data negatif dijadikan bahan masukan bagi pengembangan profesionalisme dosen PBSI dan penelitian selanjutnya.

Tabel 3 Penggunaan Strategi Perkuliahan

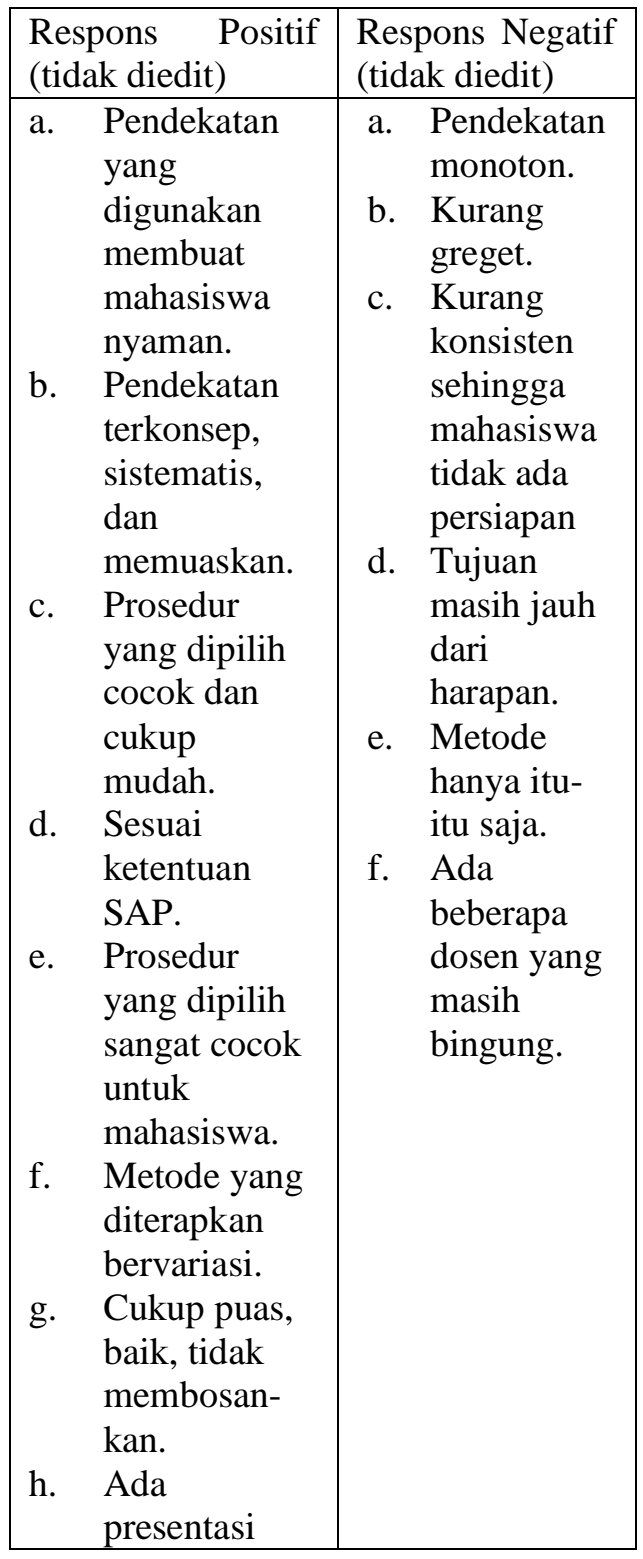

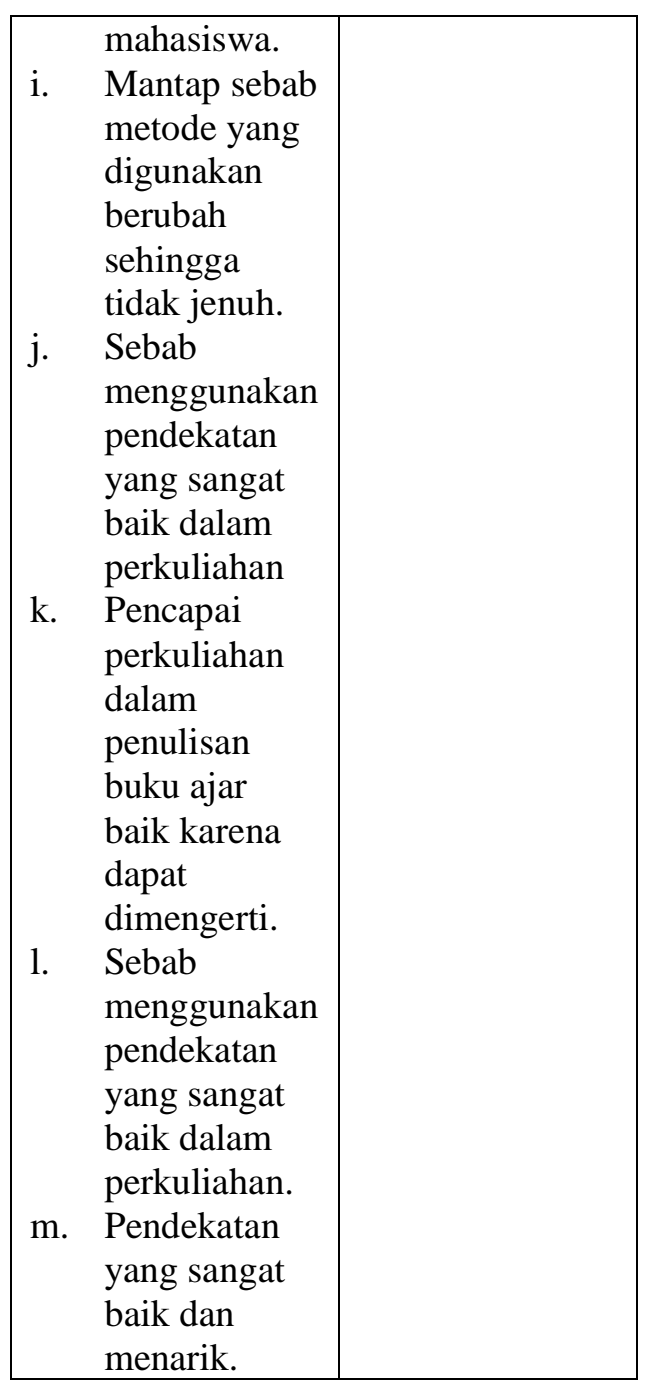

Menurut mahasiswa efektivitas kerja kelompok atau kolaborasi dalam perkuliahan sebagai berikut. Sebanyak $21 \%$ mahasiswa menyatakan sangat efektivitas (SE), 50\% mahasiswa menyatakan efektif (E), 21\% menyatakan cukup efektif (CE), dan $8 \%$ menyatakan kurang efektif (KE) seperti tampak pada diagram di bawah ini. 


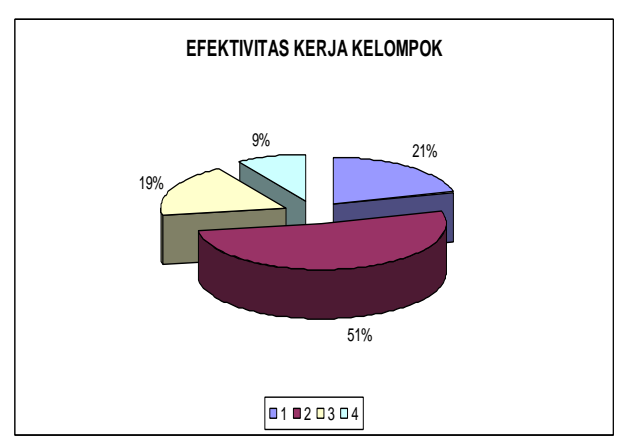

Diagram 4: Efektivitas Kerja Kelompok dalam Perkuliahan

Data persentase di atas dilengkapi dengan respons positif dan negatif berikut. Jika dibandingkan dengan aspek-aspek sebelumnya, pada efektivitas kerja kelompok ini banyak respons mahasiswa. Ini menjadi indikasi bahwa mahasiswa memandang sangat penting aktivitas dalam kerja kelompok. Respons-respons negatif secara kualitatif merupakan imun yang sangat bermakna bagi Prodi. Secara jelas respons-respons itu tersaji sebagai berikut.

\section{Tabel 4 Efektivitas Kerja Kelompok dalam Perkuliahan}

\begin{tabular}{|c|c|}
\hline $\begin{array}{l}\text { Respons Positif } \\
\text { (tidak diedit) }\end{array}$ & $\begin{array}{l}\text { Respons Negatif } \\
\text { (tidak diedit) }\end{array}$ \\
\hline $\begin{array}{l}\text { a. Disesuaikan } \\
\text { dengan } \\
\text { rangsangan } \\
\text { materi dari } \\
\text { dosen }\end{array}$ & 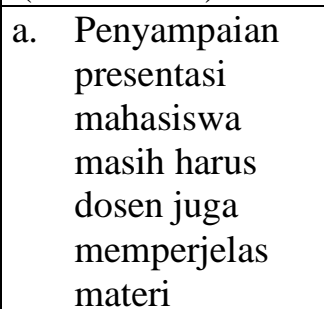 \\
\hline $\begin{array}{l}\text { b. Dalam } \\
\text { presentasi dapat } \\
\text { merangsang } \\
\text { kelompok lain } \\
\text { untuk } \\
\text { berargumentasi }\end{array}$ & $\begin{array}{ll}\text { b. } & \text { Produk masih } \\
& \text { tidak terampil }\end{array}$ \\
\hline $\begin{array}{l}\text { c. } \text { Mampu } \\
\text { berkomunikasi } \\
\text { aktif antar } \\
\text { mahasiswa }\end{array}$ & $\begin{array}{l}\text { c. Kreativitas } \\
\text { masih jauh }\end{array}$ \\
\hline
\end{tabular}

\begin{tabular}{|c|c|}
\hline $\begin{array}{l}\text { d. Efektivitas } \\
\text { belajar } \\
\text { kelompok tidak } \\
\text { ada }\end{array}$ & $\begin{array}{ll}\text { d. } & \text { Kewajiban } \\
\text { sudah } \\
\text { disampaikan } \\
\text { kepada teman } \\
\text { untuk segala } \\
\text { hal tetapi } \\
\text { jarang ada } \\
\text { respon baik } \\
\end{array}$ \\
\hline $\begin{array}{l}\text { e. Pembelajaran } \\
\text { dikerjakan } \\
\text { bersama }\end{array}$ & $\begin{array}{l}\text { e. Interaksi masih } \\
\text { lemah hanya } \\
\text { motivasi } \\
\text { sendiri }\end{array}$ \\
\hline $\begin{array}{ll}\text { f. } & \text { Masalah } \\
& \text { semuanya } \\
& \text { cukup } \\
& \text { menyenangkan } \\
\end{array}$ & $\begin{array}{ll}\text { f. } & \text { Kerja } \\
& \text { kelompok } \\
& \text { hanya untuk } \\
\text { tampil saja }\end{array}$ \\
\hline $\begin{array}{l}\text { g. Iya, } \\
\text { menstimulus } \\
\text { banget }\end{array}$ & $\begin{array}{ll}\text { g. Terlalu banyak } \\
\text { anggota malah } \\
\text { tidak efektif }\end{array}$ \\
\hline $\begin{array}{ll}\text { h. } & \text { Mudah } \\
\text { dipahami } \\
\text { setiap materi }\end{array}$ & $\begin{array}{l}\text { h. Masih banyak } \\
\text { mahasiswa } \\
\text { yang acuh tak } \\
\text { acuh }\end{array}$ \\
\hline $\begin{array}{ll}\text { i. } & \text { Bisa } \\
& \text { dikerjakan } \\
& \text { bersama tugas } \\
& \text { mahasiswa }\end{array}$ & $\begin{array}{ll}\text { i. } & \text { Kadang tidak } \\
& \text { ada tanggapan }\end{array}$ \\
\hline $\begin{array}{ll}\text { j. } & \begin{array}{l}\text { Iya } \\
\text { meningkatkan } \\
\text { banget }\end{array} \\
\end{array}$ & $\begin{array}{ll}\text { j. } & \begin{array}{l}\text { Menyebalkan } \\
\text { mending } \\
\text { individu }\end{array} \\
\end{array}$ \\
\hline $\begin{array}{ll}\text { k. } & \text { Karena dalam } \\
\text { belajar } \\
\text { kelompok } \\
\text { dapat } \\
\text { mengembangk } \\
\text { an } \\
\text { pembelajarann } \\
\text { ya } \\
\end{array}$ & $\begin{array}{ll}\text { k. } & \text { Komunikasi } \\
& \text { sedikit berjalan } \\
& \text { lancer }\end{array}$ \\
\hline $\begin{array}{l}\text { Mahasiswa } \\
\text { lebih aktif }\end{array}$ & $\begin{array}{ll}\text { 1. } & \text { Kurang } \\
\text { membangkitka } \\
\text { n kreativitas } \\
\text { dari } \\
\text { anggotanya } \\
\end{array}$ \\
\hline $\begin{array}{l}\text { m. Hasilnya } \\
\text { sesuai kerja } \\
\text { sama }\end{array}$ & 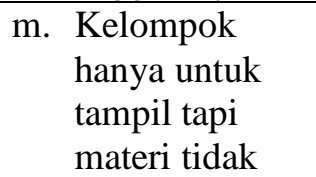 \\
\hline
\end{tabular}




\begin{tabular}{|ll|l|}
\hline n. & $\begin{array}{l}\text { Sudah tercapai } \\
\text { secara } \\
\text { produktivitas }\end{array}$ & \\
\hline o. & $\begin{array}{l}\text { Mampu } \\
\text { membangun }\end{array}$ & \\
& $\begin{array}{l}\text { kreativitas } \\
\text { belajar }\end{array}$ & \\
\hline p. & $\begin{array}{l}\text { Mampu } \\
\text { menstimulus } \\
\text { dengan baik }\end{array}$ & \\
\hline q. & $\begin{array}{l}\text { Kepuasan } \\
\text { belajar } \\
\text { kelompok } \\
\text { meningkat }\end{array}$ & \\
\hline
\end{tabular}

Aspek selanjutnya berkenaan dengan tingkat pelayanan dosen terhadap mahasiswa dalam perkuliahan pada Program Studi Pendidikan Bahasa dan Sastra Indonesia FKIP Universitas Suryakancana. Sebanyak 21\% mahasiswa menyatakan sangat memuaskan (SP), $50 \%$ mahasiswa menyatakan memuaskan (P), 21\% menyatakan cukup memuaskan (CP), dan 8\% menyatakan kurang memuaskan (KP) seperti tampak pada diagram 5 .

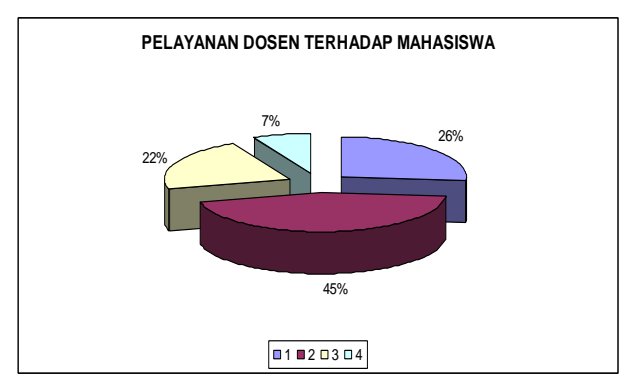

\section{Diagram 5: Pelayanan Dosen terhadap Mahasiswa dalam Perkuliahan}

Respons mahasiswa terhadap pelayanan baik yang positif maupun negatif tersaji sebagai berikut.
Tabel 5 Pelayanan Dosen terhadap Mahasiswa dalam Perkuliahan

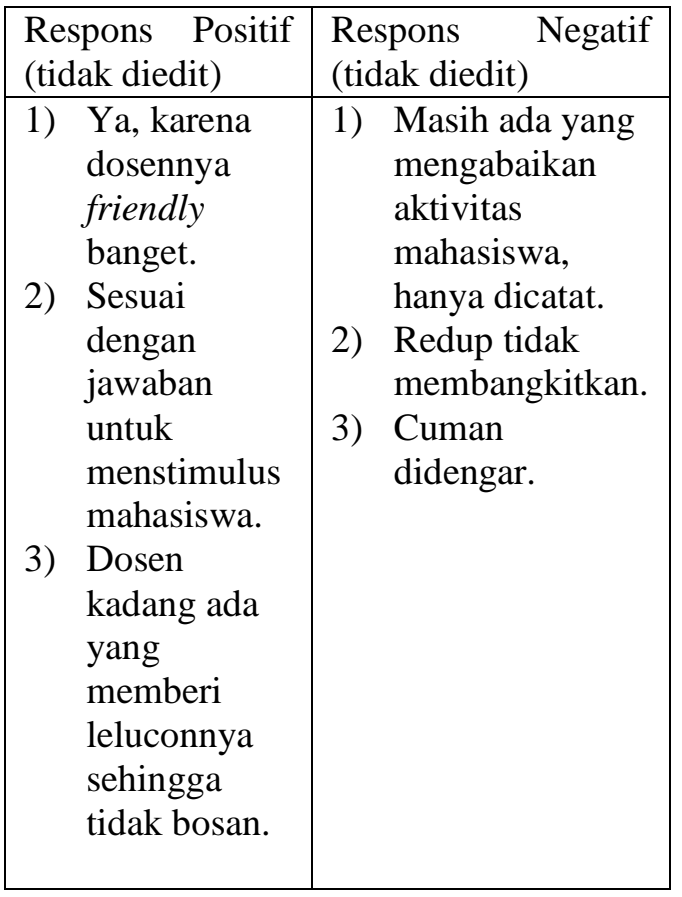

Sebagai mahluk sosial mahasiswa memandang penting perlakuan yang diterimanya sehingga jika dosen kurang optimal dalam melayaninya dengan baik berpengaruh terhadap motivasi belajar mahasiswa.

Selanjutnya, berkenaan dengan pemanfaatan alokasi waktu dalam perkuliahan rincian penilaiannya sebagai berikut. Sebanyak $21 \%$ mahasiswa menyatakan bahwa pemanfaatan alokasi waktu dalam perkuliahan sangat tepat (ST), $48 \%$ mahasiswa menyatakan tepat (T), 19\% menyatakan cukup tepat (CT), dan $12 \%$ menyatakan kurang tepat (KT). Gambaran tersebut tampak pada diagram berikut. 


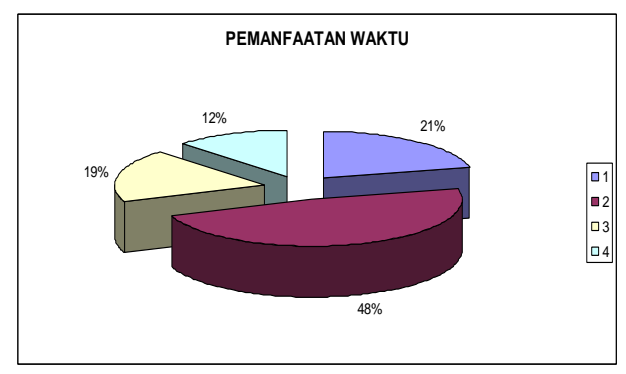

\section{Diagram 6: Pemanfaatan Waktu} dalam Perkuliahan

Hanya sedikit respons negatif berkenaan dengan pemanfaatan waktu. Artinya mahasiswa menilai sangat baik. Hal itu dapat terlihat dari respos-respons di bawah ini.

Tabel 6 Pemanfaatan Waktu dalam Perkuliahan

\begin{tabular}{|ll|ll|}
\hline $\begin{array}{l}\text { Respons Positif } \\
\text { (tidak diedit) }\end{array}$ & $\begin{array}{l}\text { Respons Negatif } \\
\text { (tidak diedit) }\end{array}$ \\
\hline a. & $\begin{array}{l}\text { Sesuai dengan } \\
\text { kesepakatan } \\
\text { waktu yang } \\
\text { ditentukan }\end{array}$ & a. & $\begin{array}{l}\text { Sedikit } \\
\text { terlambat }\end{array}$ \\
\hline b. & $\begin{array}{l}\text { Sesuai dengan } \\
\text { materi dan } \\
\text { waktu }\end{array}$ & b. & $\begin{array}{l}\text { Terkadang } \\
\text { dosen tidak } \\
\text { masuk }\end{array}$ \\
\hline c. & $\begin{array}{l}\text { Kadang tidak } \\
\text { terjadi } \\
\text { perubahan } \\
\text { jadwal }\end{array}$ & c. & $\begin{array}{l}\text { Efisien } \\
\text { sedikit } \\
\text { karena capek }\end{array}$ \\
\hline d. & $\begin{array}{l}\text { Terjalin lancar } \\
\text { e. }\end{array}$ & $\begin{array}{l}\text { dedikit } \\
\text { terlambat tak } \\
\text { masalah }\end{array}$ \\
\hline e. & $\begin{array}{l}\text { Dari awal } \\
\text { perkuliahan } \\
\text { dosen dan } \\
\text { mahasiswa } \\
\text { sudah } \\
\text { berkomitmen. }\end{array}$ & \\
\hline f. & $\begin{array}{l}\text { Selalu ada dan } \\
\text { tepat waktu }\end{array}$ & \\
\hline g. & $\begin{array}{l}\text { Sangat } \\
\text { diefesienkan }\end{array}$ & \\
\hline h. & $\begin{array}{l}\text { Sangat tepat } \\
\text { waktu }\end{array}$ & \\
\hline i. & Waktu & \\
\hline
\end{tabular}

\begin{tabular}{|ll|l|}
\hline digunakan & $\begin{array}{l}\text { sedemikian } \\
\text { efektif }\end{array}$ & \\
\hline j. & $\begin{array}{l}\text { Selalu } \\
\text { komunikasikan }\end{array}$ & \\
\hline k. & $\begin{array}{l}\text { Waktu } \\
\text { perkuliahan } \\
\text { selalu terisi }\end{array}$ & \\
\hline 1. & $\begin{array}{l}\text { Memiliki } \\
\text { komitmen yang } \\
\text { sangat baik }\end{array}$ & \\
\hline m. & $\begin{array}{l}\text { Waktu } \\
\text { perkuliahan } \\
\text { sesuai dengan } \\
\text { yang telah } \\
\text { ditetapkan }\end{array}$ & \\
\hline n. & $\begin{array}{l}\text { Waktu } \\
\text { perkuliahan } \\
\text { tepat }\end{array}$ & \\
\hline o. & $\begin{array}{l}\text { Sebelum } \\
\text { mahasiswa ada } \\
\text { sudah duluan di } \\
\text { kelas }\end{array}$ & \\
\hline p. & $\begin{array}{l}\text { Sangat tepat } \\
\text { waktu }\end{array}$ & \\
\hline q. & $\begin{array}{l}\text { Waktu } \\
\text { dimanfaatkan } \\
\text { sesuai }\end{array}$ & \\
\hline r. & $\begin{array}{l}\text { Mampu } \\
\text { memaksimalkan } \\
\text { waktu secara } \\
\text { efisien }\end{array}$ & \\
\hline s. & $\begin{array}{l}\text { Waktu yang } \\
\text { digunakan } \\
\text { efisien }\end{array}$ & \\
\hline t. & $\begin{array}{l}\text { Selama } \\
\text { perkuliahan } \\
\text { berjalan tidak } \\
\text { ada perubahan } \\
\text { jadwal }\end{array}$ & \\
\hline u. & $\begin{array}{l}\text { Selalu } \\
\text { dibicarakan } \\
\text { ketika akan } \\
\text { diubah/ditambal }\end{array}$ & \\
\hline v. & $\begin{array}{l}\text { Berkoordinasi } \\
\text { dengan sangat } \\
\text { baik }\end{array}$ & \\
\hline
\end{tabular}


Berkaitan dengan pemanfaatan media pembelajaran dalam perkuliahan pada Program Studi Pendidikan Bahasa dan Sastra Indonesia FKIP Universitas Suryakancana pada tahun 2016 rinciannya sebagai berikut. Sebanyak $21 \%$ mahasiswa menyatakan bahwa pemanfaatan media pembelajaran dalam perkuliahan sangat sesuai (SS), $50 \%$ mahasiswa menyatakan sesuai (S), 22\% menyatakan cukup sesuai (CS), dan 7\% menyatakan kurang sesuai (KS) seperti tampak dalam bagan berikut.

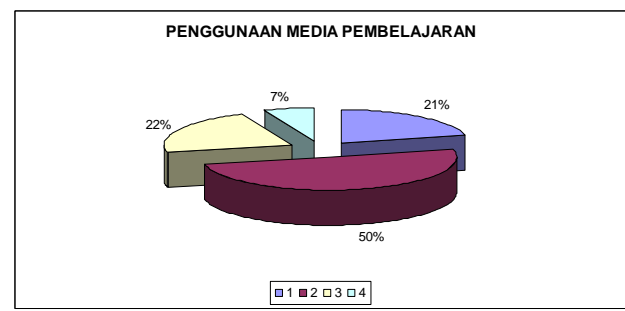

\section{Diagram 7: Pemanfaatan Media dalam Perkuliahan}

Fungsi media dalam perkuliahan sangat penting dalam perkuliahan. Hal ini terlihat dari respons positif berikut.

Tabel 7Pemanfaatan Media dalam Perkuliahan

\begin{tabular}{|c|c|}
\hline $\begin{array}{l}\text { Respons Positif } \\
\text { (tidak diedit) }\end{array}$ & $\begin{array}{c}\text { Respons } \\
\text { Negatif } \\
\text { (tidak diedit) }\end{array}$ \\
\hline $\begin{array}{l}\text { a. Memanfaatkan } \\
\text { media visual dan } \\
\text { audiovisual }\end{array}$ & $\begin{array}{l}\text { a. Media yang } \\
\text { digunakan } \\
\text { hanya } \\
\text { projektor dan } \\
\text { laptop saja }\end{array}$ \\
\hline $\begin{array}{l}\text { b. Sesuai dengan } \\
\text { kondisi kelas }\end{array}$ & $\begin{array}{l}\text { b. Tidak ada } \\
\text { variasi yang } \\
\text { digunakan }\end{array}$ \\
\hline $\begin{array}{l}\text { c. Dapat merangsang } \\
\text { mahasiswa dan } \\
\text { media baik untuk } \\
\text { selalu digunakan }\end{array}$ & \\
\hline $\begin{array}{l}\text { d. Media sesuai } \\
\text { materi }\end{array}$ & \\
\hline e. Capaian tujuan & \\
\hline
\end{tabular}

\begin{tabular}{|c|c|}
\hline $\begin{array}{l}\text { dengan } \\
\text { menggunakan } \\
\text { media sangat baik }\end{array}$ & \\
\hline $\begin{array}{l}\text { f. Media yang } \\
\text { digunakan baik. }\end{array}$ & \\
\hline $\begin{array}{l}\text { g. Sarana } \\
\text { dimanfaatkan }\end{array}$ & \\
\hline h. Sangat bervariasi & \\
\hline $\begin{array}{l}\text { i. } \begin{array}{l}\text { Sangat sesuai } \\
\text { sekali }\end{array}\end{array}$ & \\
\hline $\begin{array}{l}\text { j. } \text { Materi } \\
\text { tersampaikan } \\
\text { dengan baik. }\end{array}$ & \\
\hline $\begin{array}{l}\text { k. Dapat } \\
\text { memanfaatkan } \\
\text { media yang } \\
\text { digunakan }\end{array}$ & \\
\hline 1. Cukup baik & \\
\hline m. Sudah relevan & \\
\hline $\begin{array}{l}\text { n. Mahasiswa dapat } \\
\text { menggunakan } \\
\text { beberapa dalam } \\
\text { pembelajaran }\end{array}$ & \\
\hline $\begin{array}{l}\text { o. Media mengubah } \\
\text { yang verbalistik }\end{array}$ & \\
\hline $\begin{array}{l}\text { p. Sangat bermanfaat } \\
\text { media yang } \\
\text { digunakan }\end{array}$ & \\
\hline $\begin{array}{l}\text { q. Media ada sedikit } \\
\text { warna }\end{array}$ & \\
\hline $\begin{array}{l}\text { r. Tampilannya } \\
\text { bervariasi } \\
\text { sehingga menraik }\end{array}$ & \\
\hline $\begin{array}{l}\text { s. Media dapat } \\
\text { memperjelas yang } \\
\text { verbalisme }\end{array}$ & \\
\hline $\begin{array}{l}\text { t. Sangat sesuai } \\
\text { media dengan } \\
\text { materinya }\end{array}$ & \\
\hline $\begin{array}{l}\text { u. Tujuan dapat } \\
\text { dicapai }\end{array}$ & \\
\hline $\begin{array}{l}\text { v. Sudah sangat } \\
\text { tercapai }\end{array}$ & \\
\hline
\end{tabular}

Penilaian mahasiswa terhadap pengorganisasian kelas dalam pelaksanaan pembelajaran pada Program Studi 
Pendidikan Bahasa dan Sastra Indonesia FKIP Universitas Suryakancana pada tahun 2016 dapat dirinci sebagai berikut. Sebanyak $18 \%$ mahasiswa menyatakan sangat baik (SB), 48\% mahasiswa menyatakan baik (B), 23\% menyatakan cukup baik (CB), dan $11 \%$ menyatakan kurang baik (KB) seperti tergambar pada diagram berikut.

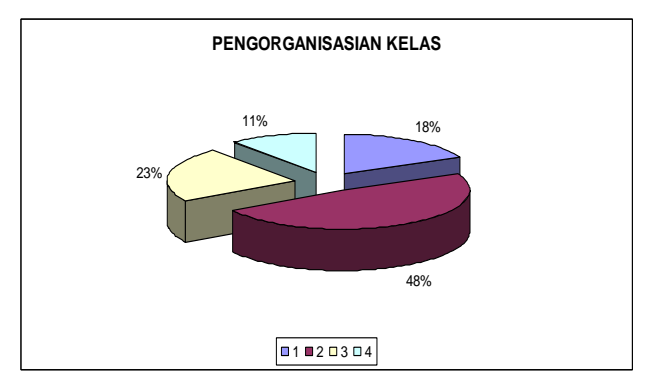

\section{Diagram 8: Pengorganisasian Kelas dalam Perkuliahan}

Diskusi merupakan kegiatan yang lazim digunakan dalam pengorganisasian kelas. Mahasiswa memandang positif kegiatan ini. Respons negatif memandang masih ada dosen kaku dalam mengorganisasikan mahasiswa, seperti terdapat pada daftar respons berikut.

\section{Tabel 8 Pengorganisasian Kelas} dalam Perkuliahan

\begin{tabular}{|c|c|}
\hline $\begin{array}{ll}\text { Respons } & \text { Positif } \\
\text { (tidak diedit) }\end{array}$ & $\begin{array}{l}\text { Respons Negatif } \\
\text { (tidak diedit) }\end{array}$ \\
\hline $\begin{array}{ll}\text { a. } & \begin{array}{l}\text { Diskusi yang } \\
\text { digunakan di } \\
\text { kelas dapat } \\
\text { mengeratkan }\end{array} \\
\text { kerja sama. } \\
\text { b. } \\
\text { Arus } \\
\text { komunikasi } \\
\text { antara } \\
\text { mahasiswa } \\
\text { dengan dosen } \\
\text { baik. } \\
\text { c. Dosen } \\
\text { menyampaikan } \\
\text { terlebih dahulu }\end{array}$ & $\begin{array}{ll}\text { a. } & \text { Hanya } \\
& \text { sedikit } \\
& \text { komunikasi } \\
& \text { berjalan. } \\
\text { b. } & \text { Masih ada } \\
& \text { dosen yang } \\
\text { kaku }\end{array}$ \\
\hline
\end{tabular}

\begin{tabular}{|l|l|}
\hline d. & Materi. \\
& diikutsertakan \\
& dalam \\
& pengelolaan \\
& perkuliahan. \\
e. & Terdapat \\
& penilaian proses \\
& selama \\
& perkuliahan. \\
f. & Tugas sudah \\
& disesuaikan \\
& sehingga tidak \\
& menjadi beban. \\
g. & Selalu \\
& berkelompok \\
& dan saling \\
& memberi tahu. \\
h. & Sebab \\
& menggunakan \\
pendekatan yang & \\
sangat baik & dalam \\
perkuliahan & \\
\hline
\end{tabular}

Jika dicermati respons yang berupa penilaian mahasiswa terhadap perkuliahan berdasarkan data yang ada pada umumnya berada pada kategori baik pada semua aspek, yaitu aspek kualitas materi perkuliahan, penguasaan dosen terhadap materi perkuliahan, penggunaan strategi perkuliahan, efektivitas kerja kelompok atau kolaborasi dalam perkuliahan, pelayanan dosen terhadap mahasiswa dalam perkuliahan, pemanfaatan alokasi waktu dalam perkuliahan, pemanfaatan media pembelajaran dalam perkuliahan, dan dalam hal pengorganisasian kelas dalam pelaksanaan pembelajaran. Aspek-aspek itu dominan ditanggapi sebagai hal yang sangat memuskan (SP) atau memuaskan $(\mathrm{P})$, tetapi tidak berarti semua mahasiwa menyatakan sangat memuaskan/puas. Sebagian masih menyatakan 
bahwa perkuliahan pada Program Studi Pendidikan Bahasa dan Sastra Indonesia kurang memuaskan (KP) atau bahkan sangat tidak memuaskan (KP).

Hal yang perlu dikemukakan pada bagian ini adalah tidak diperoleh informasi lebih mendalam penjelasan mengapa mereka puas atau tidak puas pada setiap aspek karena instrumen yang digunakan hanya mampu menggali data yang terlalu umum. Dengan demikian, sebaiknya hasil penelitian ini dijadikan sebagai data awal yang perlu ditindaklanjuti dengan penelusuran lebih jauh.

Berikut akan dikemukakan rekapitulasi hasil kuiesioner kuantitatif seperti tersaji berikut.

Tabel 9 Rekapitulasi Data Kuantitatif Hasil Kuesioner terhadap Perkuliahan

\begin{tabular}{|c|c|c|c|c|c|}
\hline Aspek & SP & $\mathbf{P}$ & $\mathbf{C P}$ & $\begin{array}{c}\text { K } \\
\mathbf{P}\end{array}$ & $\begin{array}{c}\text { JUML } \\
\text { AH }\end{array}$ \\
\hline 1 & 21 & 50 & 21 & 8 & 100 \\
\hline 2 & 25 & 46 & 21 & 8 & 100 \\
\hline 3 & 21 & 48 & 24 & 7 & 100 \\
\hline 4 & 21 & 50 & 21 & 8 & 100 \\
\hline 5 & 21 & 50 & 21 & 8 & 100 \\
\hline 6 & 21 & 48 & 19 & 12 & 100 \\
\hline 7 & 21 & 50 & 22 & 7 & 100 \\
\hline 8 & 18 & 48 & 23 & 11 & 100 \\
\hline $\begin{array}{c}\text { JUML } \\
\text { AH }\end{array}$ & 169 & 390 & 172 & 70 & \\
\hline $\begin{array}{c}\text { Rata- } \\
\text { rata }\end{array}$ & 21. & 18 & 48. & 21. & 8 \\
\hline
\end{tabular}

Dari Tabel di atas diketahui bahwa jumlah responden terhadap aspek-aspek yang diteliti untuk rata-rata sangat puas ada $21.12 \%$ dan puas 48.38 $\%$. Kedua kategori ini jika dijumlahkan $70,04 \%$. Artinya responden menilai baik terhadap pelaksanaan perkuliahan. Meskipun angka persentase ini tidak terlampau tinggi, namun jika dibanding dengan persentase akumulasi dari cukup puas 21.28 dengan kurang puas 8.66 yakni $29.96 \%$ selisihnya cukup jauh.
Data tersebut relevan dengan hasil evaluasi penjamin mutu FKIP tahun 2016 (lihat laporan Evaluasi Penjamin Mutu FKIP UNSUR Tahun 2016).

\section{SIMPULAN}

Mahasiswa memandang penting terhadap aspek-aspek yang ditanyakan. Hal ini terbukti dengan tingginya persentase respons yang masuk. Partisipasi mahasiswa sebagai responden sang-at penting bagi peningkatan kualitas program studi. Sebagai Lembaga Pendidikan Tenaga Kependidikan (LPTK), PBSI FKIP Universitas Suryakancana berkomitmen untuk berupaya untuk menjadi lebih baik dan lebih berkualitas sehingga penilaian mahasiswa sebagai subjek terdidik diperhitungkan. Penilaian mahasiswa merupakan bagian dari penilaian internal. Secara internal penilaian itu dilakukan oleh lembaga penyelenggara yang bersangkutan, baik dilakukan pada tataran universitas, fakultas, program studi, dosen, dan mahasiswa. Selain itu, Prodi PBSI secara berkala melakukan penilaian secara eksternal melalui BAN-PT sebagai salah satu lembaga akreditasi.

Mahasiswa sebagai bagian dari sumber daya manusia program studi, pada penelitian ini menjadi subjek penelitian yang menilai kualitas Program Studi Pendidikan Bahasa dan Sastra Indonesia secara internal. Melalui kuesioner Model Bull Eyes diteliti delapan aspek yang bersangkutan, yakni kualitas materi perkuliahan, penguasaan dosen terhadap materi perkuliahan, penggunaan strategi perkuliahan, pelayanan dosen terhadap mahasiswa penggunaan media pembelajaran, efektivitas pembelajaran kelompok, pengorganisasian kelas, dan pemanfaatan waktu.

Berdasarkan analisis data kuantitatif dan kualitatif dapat diketahui hasil penilaian terhadap kedelapan aspek yang 
diteliti. Mahasiswa menilai baik terhadap kedelapan aspek. Hal itu diketahui baik secara kuantitatif maupun kualitatif. Secara kuantitatif, persentase kuesioner yang menyatakan sangat puas dan puas, responsnya lebih tinggi dibandingkan dengan yang menyatakan cukup puas dan kurang puas. Secara kualitatif, respons positif mahasiswa lebih banyak dibandingkan dengan respons negatif.

Penelitian ini beroleh saran untuk empat aspek yang diteliti, yakni: 1) untuk peningkatan kualitas materi perkuliahan: masih diperlukan perluasan sumber rujukan bahan ajar. Mahasiswa menilai tidak tepat jika diktat dijadikan satu-satunya rujukan perkuliahan. 2) Dosen hendaknya piawai dalam menciptakan dan menggunakan media pembelajaran. Mahasiswa berharap dosen dapat mengatasi masalah penggunaan media jika terjadi masalah pada saat perkuliahan di kelas. 3) Efektivitas pembelajaran kelompok yang berupa diskusi, mahasiswa mengharapkan ada konfirmasi dan verifikasi dari dosen. Artinya, mahasiswa sangat memerlukan penjelasan dari dosen tentang kebenaran materi yang disajikan kelompok pada saat presentasi di kelas. 4) Untuk waktuk perkuliahan, mahasiswa menginginkan perkuliahan berjalan sesuai dengan jadwal yang telah ditentukan.

\section{DAFTAR PUSTAKA}

Badan Pengembangan Sumber Daya Manusia Pendidikan dan Kebudayaan dan Penjaminan Mutu Pendidikan Kementerian Pendidikan dan Kebudayaan 2014. Materi pelatihan guru implementasi kurikulum 2013 tahun 2014 sd kelas iv.

Brown, H. Douglas. 2007. Prinsip pembelajaran dan pengajaran bahasa. Edisi kelima. Jakarta:
Kedutaan Besar Amerika Serikat.

Fattah, Nanang. 2001. Landasan manajemen pendidikan. Bandung : Remaja Rosdakarya

Hidayat, Kosadi, dan Iim Rahmina. 1991. Perencanaan pengajarann bahasa indonesia. $\mathrm{Tt}$ : Binacipta.

http://www.kompasiana.com/trendiadza nwahyudi/teori-pembelajaranstimulus-

respons 552e4bcb6ea834133f8 b4593 DIUNDUH 3-2-2016 8: 03

Maryam, Siti. 2006. Pengembangan kreativitas berbahasa dalam menulis esai.

Disertasi. UPI Bandung.

Munadi, Yudhi. 2013. Media pembelajaran. Jakarta :Referensi (GP Press group).

Nurgiyantoro, Burhan. 2011. Penilaian pembelajaran bahasa. BPEE Yogyakarta.

Nugraheni, Aninditya Sri. 2012. Pengembangan strategi pembelajaran technical writing dengan collaborative writing untuk memperbaiki kualitas mata kuliah bahasa indonesia di ptain. Yogyakarta: Lembaga Penelitian UIN Sunan Kalijaga. Tersedia Online http://digilib.uin-suka.ac.id.

Nurhayati, Eti. 2011. Psikologi pendidikan inovatif. Yogyakarta : Pustaka Pelajar.

Rusman. 2011. Model- model pembelajaran mengembangkan profesional guru. Jakarta: Rajawali Pers

Sagala, Syaiful. 2007. Konsep dan makna pembelajaran. Bandung: Alfabeta.

Standar Nasional Pendidikan Tinggi: Berdasarkan Permendikbud 
Nomor 49/2014

https://www.google.co.id/?gws

$\mathrm{rd}=\mathrm{ss}$ l\#q=PRINSIP+PEMBELA

JARAN+DALAM+SNDIKTI

diunduh 4 Maret 2016 pukul 11: 25

Sudirman, dkk. 1991. Ilmu pendidikan.

Bandung: Remaja Rosdakarya.

Tarigan, Henry Guntur.1991. Strategi Pengajaran dan Pembelajaran Bahasa. Bandung: Angkasa.

Wulyo. 1990. Kamus psikologi. 149.

CV. Bintang Pelajar. 